\title{
Development and Implementation of Curriculum Adaptation During The Covid-19 Pandemic
}

\author{
Muh Syauqi Malik \\ Sunan Kalijaga State Islamic University, Yogyakarta, Indonesia \\ syauqi.pendidikan@gmail.com \\ Sukiman \\ Sunan Kalijaga State Islamic University, Yogyakarta, Indonesia \\ sukiman@uin-suka.ac.id
}

\begin{abstract}
The outbreak of the Covid-19 pandemic has penetrated all people globally, including the Indonesian people who feel that the teaching and learning culture must follow health protocols. Still, the learning process must continue even though it is limited. This study aims to determine curriculum adaptation during the Covid-19 pandemic, teacher strategies, and its impact on MI Salafiyah Tajungsari and SDN Sitiluhur 02. This type of research used qualitative field studies with data sources for school principals, curriculum development teams, and teachers. Methods of data collection using observation, interviews, and documentation. Data analysis includes data reduction, data presentation, concluding, and verification. The technique of testing the validity of the data used triangulation of sources and methods. The research findings showed that MI Salafiyah Tajungsari uses an emergency curriculum with essential materials, while SDN Sitiluhur 02 uses a curriculum that simplifies critical competencies. The learning strategies used by teachers include online and offline. The difference lies offline. Offline at MI Salafiyah Tajungsari held limited face-toface meetings, while offline at SDN Sitiluhur 02, students carried out the tasks assigned by the teacher and submitted their work to school. The impact of the adaptation curriculum has made the competency target of the school not maximally achieved.
\end{abstract}

Keywords: Adaptation Curriculum; Teacher Strategy; Impact; Covid-19. 


\begin{abstract}
Abstrak
Wabah pandemi Covid-19 merambah ke seluruh masyarakat di dunia, tak terkecuali bangsa Indonesia ikut merasakan hingga budaya belajar mengajar harus mengikuti protokol kesehatan, namun proses pembelajaran harus tetap berjalan walau dalam keterbatasan. Penelitian ini bertujuan untuk mengetahui bentuk adaptasi kurikulum masa pandemi Covid-19, strategi guru, dan dampaknya di MI Salafiyah Tajungsari dan SDN Sitiluhur 02. Jenis penelitian menggunakan kualitatif studi lapangan dengan sumber data kepala sekolah, tim pengembang kurikulum, dan guru. Metode pengumpulan data menggunakan observasi, wawancara, dan dokumentasi. Analisis data meliputi reduksi data, penyajian data, penarikan kesimpulan dan verifikasi. Teknik uji keabsahan data menggunakan triangulasi sumber dan metode. Temuan penelitian menunjukkan bahwa MI Salafiyah Tajungsari menggunakan kurikulum darurat dengan materi esensial, sedangkan SDN Sitiluhur 02 menggunakan kurikulum dengan menyederhanakan kompetensi dasar. Strategi pembelajaran yang digunakan oleh guru meliputi daring dan luring, bedanya terletak di luring. Luring di MI Salafiyah Tajungsari melaksanakan tatap muka terbatas, sedangkan luring di SDN Sitiluhur 02 peserta didik menunaikan tugas yang diberikan oleh guru, dan menyerahkan hasil karyanya di sekolah. Dampak kurikulum adaptasi menjadikan target kompetensi sekolah belum tercapai secara maksimal.
\end{abstract}

Kata kunci: Kurikulum Adaptasi; Strategi Guru; Dampak; Covid-19.

\title{
A. Introduction
}

The advancement of education determines the progress of a nation's civilization in the government, the more advanced the education of a nation's society is increasing, as well as the nation's economy is also growing because the educated population will be able to face various challenges in the existing problems (Hidayati, 2016). Education in academic units is usually designed to realize educational programs and measure educational achievement levels in academic departments (Julaeha, 2019). A curriculum is an educational program to organize and organize matters related to academic interests. The curriculum emphasizes the subject matter and includes all learning experiences conducted by madrasah to positively impact the personal development of students following educational objectives (Sukirman \& Nugraha, 2018). The curriculum is constantly evolving and undergoing improvements and revisions to deal with the demands of the developing age (Cahyani \& Satriyani, 2020).

Various steps and processes of curriculum making have been made carefully. Still, Indonesia and even foreign countries get a very severe trial in the form of the outbreak of the 
Covid-19 virus. The emergence of severe diseases of acute respiratory syndrome Covid-19 was discovered by Novel Coronavirus in China at the end of 2019, which has caused a sizeable global outbreak and is a significant public health problem (Lai, Shih, Ko, Tang, \& Hsueh, 2020). Another source stated the discovery of severe acute respiratory syndrome coronavirus 2 (SARS-CoV-2), a new, more contagious coronavirus strain disease, more than 600,000 confirmed cases, and increased deaths in China (Giannis, Ziogas, \& Gianni, 2020). As of July 12,2020 , the virus has been responsible for $12,698,995$ confirmed cases, and 564,924 deaths worldwide, and the number continues to rise. To date, no specific treatment has been proven effective against SARS-CoV-2 (Bchetnia, Girard, Duchaine, \& Laprise, 2020).

The Ministry of Education issued a policy on curriculum during the Covid-19 pandemic. First, the education unit is allowed to continue to use the national curriculum. Second, the education unit uses an emergency curriculum. Third, the education unit simplifies the existing curriculum. The Ministry of Education provides the amplest opportunity to explore the policies that the education unit will take based on the three options tailored to the situation and conditions of each school (Ministry of Education and Culture Website Manager, 2020). Meanwhile, the Ministry of Finance compiled emergency curriculum guidelines that need to be implemented by madrasah through the director-general's decision of Islamic education no. 2791 of 2020, which serves as the basis for the education unit Raudlatul Athfal level to Madrasah Aliyah in the emergency period. The Directorate General of Islamic Education has made efforts to build madrasah e-learning applications, provide electronic textbooks, and support the creation of learning videos (Director-General of Islamic Education, 2020).

Based on observations made by researchers at MI Salafiyah Tajungsari, students undergo online and offline learning. Online learning still causes a variety of unrest felt by various parties. Complaints submitted by the parents, among others, and carrying out daily tasks, should educate their children. Of course, it is very troublesome for parents who do not have primary education, such as mathematics. Observations were made on October 19, 2020.

Based on observations made by the author at SDN Sitiluhur 02, the author found that students are getting bored and saturated because of learning from home and not being able to meet their peers and sometimes challenging to understand the learning delivered by educators. Although teachers have done distance learning techniques by paying attention to the condition of students, there are still students who are less able to capture learning well. Observations were made on October 21, 2020. 
The impact of distance learning has more complex obstacles than face-to-face learning (Rigianti, 2020). Some barriers experienced by students, such as difficulty in understanding the material delivered by the teacher. Teaching materials in the 2013 curriculum include critical and creative thinking, communicative learning, and collaboration (Prastowo \& Fitriyaningsih, 2020). Obstacles in understanding the material can occur because not all students have the same competencies. Students come from different families, so the family's economic income is other, and students desperately need adaptation to the learning process that is a relatively new course.

The type of research conducted by the authors uses qualitative approaches to field studies with observation techniques, interviews, and documentation. The research was conducted in MI Salafiyah Tajungsari Tlogowungu Subdistrict, Pati Regency and SDN Sitiluhur 02, Gembong Subdistrict, Pati Regency, from February 1 to February 28, 2021. Initially, the research design was prepared based on efforts to provide solutions to the Covid19 pandemic problem, especially in the education sector. Then determine the location of the research, respondents, and informants be studied. Data collection is done through observation techniques, interviews, and documentation. The data of field research results are displayed as research findings. Abstraction is conducted to obtain information in its entirety and interpreted to be understood until drawn conclusions. After the above series of activities are completed, the last step that needs to be done is to conclude the research that has been done (Darmalaksana, 2020).

The data sources used in this study include principals, curriculum development teams, and teachers (Representatives of Upper-Class Teachers, Representatives of Low-Class Teachers, Representatives of Islamic Religious Education Teachers, and Physical Education Teachers of Sports and Health) from both MI Salafiyah Tajungsari Tlogowungu Subdistrict, Pati Regency and SDN Sitiluhur 02, Gembong Subdistrict, Pati Regency. Researchers are flexible in accessing curriculum documents at academic units from both MI Salafiyah Tajungsari institutions and SDN Sitiluhur 02 institutions. Researchers also used data sources from the Ministry of Education and Culture decisions and the Ministry of Religious Affairs of the Republic of Indonesia, and other Government Decisions related to curriculum adaptation during the Covid-19 pandemic.

The authors conducted data analysis using theories put forward by Miles and Huberman, including data reduction, data presentation, conclusion drawing, and verification. Data reduction is the process of selecting, focusing, abstracting data, and transforming rough data that arises from author records in the field (Miles \& Huberman, 2009, p. 16). 
Presentation of data in other meanings of the word collecting information and the possibility of funds for good business cards (Miles \& Huberman, 2009, p. 17). Drawing conclusions based on data obtained from the field, verification is a review of field records to ensure that data must be tested for correctness, correctness, and robustness (Miles \& Huberman, 2009, p. 19).

The data validity test technique used by researchers is triangulation. Triangulation is used to test the validity and reliability of research data. The researchers used triangulation of resources from the Principal, Curriculum Development Team, Grade 2 Teacher, Grade 4 Teacher, PAI Teacher, and Physical Education Teachers of Sports and Health Teacher from MI Salafiyah Tajungsari and SDN Sitiluhur 02. Researchers also used triangulation methods in relationships between data obtained through observations, interviews, and documentation.

This research is critical to be carried out because there has not been any other research that discusses curriculum adaptation in the era of the Covid-19 pandemic. As well the study by Dini Fauziyati has a focus on curriculum development in universities (Fauziyati, 2019), Ezza Dwi Audia's research that discusses the comparative application of Islamic education curriculum in Indonesia and Malaysia (Audia, 2019), Wahdan Najib Habiby et al. on the application of curriculum 2013 in schools (Habiby, 2017). Similarly, Sukino's research on the adaptation of the curriculum in transitional areas (Sukino, 2017), Suharsiwi research focusing on curriculum development based on inclusion classes (Soeratman, 2016), Dedi Supriatna and Siti Ratnaningsih's research on the adaptation of madrasah curriculum to global challenges (Supriatna \& Ratnaningsih, 2017), analysis of Apri Damai Sagita Krissandi and Rusmawan which only discussed the constraints of curriculum implementation (Krissandi \& Rusmawan, 2015), and Agung Winarno's research on curriculum adaptation by implementing character values (Winarno, 2015).

Teachers during the Covid-19 pandemic are required to have a more creative and innovative learning strategy even though it is full of limitations. Teachers must devote their energy, time, and mind to making learning plans, learning media, and evaluations more complex than usual. Therefore, more research is needed on how to develop and implement the curriculum during the Covid-19 pandemic. The author is interested in researching "Development and Implementation of Curriculum adaptation during the Covid-19 Pandemic at MI Salafiyah Tajungsari and SDN Sitiluhur 02". 


\section{B. Discussion}

\section{Form of Curriculum Adaptation during the Covid-19 Pandemic}

The original curriculum originated in the world of sports during ancient Rome in Greece, which meant that runners had to travel from start to finish to get awards. Furthermore, the curriculum is devoted to the field of education, which means a subject that needs to be taken to obtain a diploma (Arifin, 2011, p. 3). The curriculum is the core of the learning system. Without the curriculum, the learning process becomes unclear direction and orientation (Maslahah, 2018). Curriculum in the form of materials prepared in learning to print competent learners (Kamilati, 2018). The curriculum is a guideline used in carrying out the learning process at various levels of education planned in an organized manner to create an optimal learning experience for students under the auspices of educational institutions to achieve academic goals (Hariyanto, 2019).

The curriculum, in general, is a series of all program activities that have been planned and applied by each educational institution. The curriculum is not a draft of subjects but all activities in education. Starting from the learning centre to students or educators, the necessary facilities in learning and the whole thing related to learning serve to foster and develop students who are knowledgeable, moral, and righteous (Asnawan, 2018). Curriculum as a plan with the curriculum as an inseparable reality (Bahrissalim \& Fauzan, 2018). Based on various understandings, more or less can be grouped into three groups. First, the group that defines the curriculum is the action plan that will be carried out. Second, the group that establishes the curriculum is the learning process. Third, the group defines the curriculum very broadly, namely the process carried out by learners in their learning experience and related to it (Suparlan, 2012, p. 39).

Curriculum development is a series of processes that start from designing, implementing, evaluating, and improving the curriculum to form an ideal curriculum (Sukiman, 2015, p. 6). Curriculum development can also be stated as planning the curriculum to produce a specific and extensive curriculum plan. These matters relate to the selection and organizing process of learning components such as setting curriculum organizational schedules, formulating objectives, subjects, activities, resources, and evaluation of curriculum development to facilitate the learning process (Hamalik, 2013, p. 184).

The curriculum formulated and developed has several functions, including forming intelligent and virtuous learners following the vision, mission, and national educational objectives (Arifin, 2011, p. 13). The curriculum is a guideline in designing the learning process 
to be applied, curriculum as a guideline in implementing its work program as an effort to organize the learning experience of learners, as a guideline in conducting evaluations to know the extent to which learners achieve the expected learning goals (Idi, 2014, p. 165). The madrasah/school curriculum head is a guideline in guiding and organizing activities in madrasah/school daily (Arifin, 2011, p. 12). The curriculum also serves as a guideline in carrying out supervision to know the extent to which curriculum realization has been running to improve the learning system (Idi, 2014, p. 166).

The principles used in curriculum development include: First, Relevance which means the purpose, content, methods, processes, and evaluation of learning relevant to the demands of society and the progress of the times. Second, the curriculum should be flexible, able to adapt to the situation and conditions experienced. Third, the curriculum must be implemented continuously, meaning that it can accommodate the development of students according to their age. Fourth, the curriculum should be practical so that it is easy to implement (Arifin, 2018, p. 69). A good curriculum is a curriculum that can develop the potential of learners with whatever characteristics and background of learners (Atiqoh \& Saputro, 2017).

Learning in the pandemic era creates a challenge because a teacher is required to carry out many additional roles and be able to adjust to distance learning while achieving the expected learning targets. Therefore, the curriculum applied by MI Salafiyah Tajungsari is not the same as the period before the covid-19 pandemic because, during the Covid-19 pandemic, MI Salafiyah Tajungsari implemented the Emergency Curriculum. Emergency Curriculum is a curriculum designed and implemented by the education unit in the emergency period with attention to the boundaries that have been set. The emergency curriculum was created so that all students continued to receive educational services even during the Covid-19 pandemic. Activities carried out in times of emergency do not focus on material completion but rather strengthen character, care for the environment, practice in worship, and other social piety. Implement learning using online and offline models by paying attention to learning facilities in the students' homes.

The curriculum simplification in MI Salafiyah Tajungsari refers to developing essential materials carried out by the Director of Curriculum, Facilities, Institutions, and Students (Director of Curriculum, Facilities, Institutions, and Students, 2020). Simplification of the curriculum is only done to KI-3 (area of knowledge). The authors exemplify the 2013 curriculum comparison (Minister of Education and Culture, 2016) with the emergency curriculum of the Covid-19 pandemic in Grade 2 MI Salafiyah Tajungsari to clarify the reader's 
understanding further. The author took the example of grade 4 because all classes are the same, only using essential material (Head of Research and Development Agency, 2020).

Figure 1. Curriculum Comparison 2013 number 24 the Year 2016 Appendix 18 with Curriculum Adaptation MI Salafiyah Tajungsari

\begin{tabular}{|c|c|c|c|}
\hline \multicolumn{2}{|r|}{ KOMPETENSI DASAR } & \multicolumn{2}{|r|}{ KOMPETENSI DASAR } \\
\hline 3.1 & $\begin{array}{l}\text { Memahami makna hubungan } \\
\text { simbol dengan sila-sila Pancasila }\end{array}$ & 4.1 & $\begin{array}{l}\text { Menjelaskan makna hubungan } \\
\text { simbol dengan sila-sila Pancasila } \\
\text { sebagai satu kesatuan dalam } \\
\text { kehidupan sehari-hari }\end{array}$ \\
\hline 3.2 & $\begin{array}{l}\text { Mengidentifikasi pelaksanaan } \\
\text { kewajiban dan hak sebagai warga } \\
\text { masyarakat dalam kehidupan } \\
\text { sehari-hari }\end{array}$ & 4.2 & $\begin{array}{l}\text { Menyajikan hasil identifikasi } \\
\text { pelaksanaan kewajiban dan hak } \\
\text { sebagai warga masyarakat dalam } \\
\text { kehidupan gehari-hari }\end{array}$ \\
\hline 3.3 & $\begin{array}{l}\text { Menjelaskan manfaat } \\
\text { keberagaman lcarakteristik } \\
\text { individu dalam kehidupan sehari- } \\
\text { hari }\end{array}$ & 4.3 & $\begin{array}{l}\text { Mengemukakan manfaat } \\
\text { lceberagaman karakteristik } \\
\text { individu dalam kehidupan sehari- } \\
\text { hari }\end{array}$ \\
\hline 3.4 & $\begin{array}{l}\text { Mengidentifikasi berbagai bentuk } \\
\text { keberagaman sulku bangsa, sosial, } \\
\text { dan budaya di Indonesia yang } \\
\text { terikat persatuan dan kesatuan }\end{array}$ & 4.4 & $\begin{array}{l}\text { Menyajikan berbagai bentuk } \\
\text { keberagaman suku bangsa, sosial, } \\
\text { dan budaya di Indonesia yang } \\
\text { terikat persatuan dan kesatuan }\end{array}$ \\
\hline
\end{tabular}

\begin{tabular}{|c|c|c|c|c|c|c|}
\hline & \multicolumn{6}{|c|}{$\begin{array}{l}\text { MATERI ESENSIAL } \\
\text { PKN "4" }\end{array}$} \\
\hline No & & KD & INOIKATOR & TUUUAN & Materi & Level \\
\hline \multirow[b]{2}{*}{1} & \multirow[b]{2}{*}{ KD 3.1} & \multirow[b]{2}{*}{$\begin{array}{l}\text { Memahami makna hubungan simbo } \\
\text { dengan sila - sila pancasila }\end{array}$} & $\begin{array}{l}\text { Menjelaskan hubungan simbol } \\
\text { dengan makna sila - sila Pancasila }\end{array}$ & $\begin{array}{l}\text { Siswa mampu menjelaskan hubungan } \\
\text { simbol dengan makna sila - sila } \\
\text { Pancasila }\end{array}$ & $\begin{array}{l}\text { Makna hubungan simbol } \\
\text { dengan sila - sila pancasila }\end{array}$ & \multirow[b]{2}{*}{$\mathrm{C}_{2}$} \\
\hline & & & $\begin{array}{l}\text { Mengkklasifikasi sikap yang baik dan } \\
\text { sikap yang tidak baik dikaitkan } \\
\text { dengan makna dan nilai - nilai } \\
\text { Pancasila }\end{array}$ & $\begin{array}{l}\text { Siswa mampu mengklasifikasi sikap } \\
\text { yang baik dan sikap yang tidak baik } \\
\text { dikaitikan dengan makna dan nilai- } \\
\text { nilai Pancasila }\end{array}$ & \begin{tabular}{|l|}
$\begin{array}{l}\text { Klasifikasi sikap baik dan } \\
\text { sikap tidak baik sesuai } \\
\text { dengan nilai - nilai Pancasila }\end{array}$ \\
\end{tabular} & \\
\hline \multirow{4}{*}{2} & \multirow{4}{*}{ KD 3.2} & \multirow{4}{*}{$\begin{array}{l}\text { Mengidentifikasi pelaksanaan } \\
\text { kewajiban dan hak sebagai warga } \\
\text { masyarakat dalam kehidupan sehari } \\
\text { hari }\end{array}$} & $\begin{array}{l}\text { Mengidentifikasi contoh } \\
\text { pelaksanaan kewajiban dirumah }\end{array}$ & $\begin{array}{l}\text { Siswa mampu mengidentifikasi } \\
\text { contoh pelaksanaan kewajiban } \\
\text { dirumah }\end{array}$ & Contoh kewajiban dirumah & \multirow{4}{*}{ c1 } \\
\hline & & & $\begin{array}{l}\text { Mengidentifikasi contoh } \\
\text { pelaksanaan hak dirumah }\end{array}$ & $\begin{array}{l}\text { Siswa mampu mengidentifikasi } \\
\text { contoh pelaksanaan hak dirumah }\end{array}$ & Contoh hak dirumah & \\
\hline & & & $\begin{array}{l}\text { Menjelaskan perbedaan } \\
\text { pelaksanaan kewajiban dan hak } \\
\text { dirumah }\end{array}$ & $\begin{array}{l}\text { Siswa mampu mengidentifikasi } \\
\text { contoh pelaksanaan kewajiban dan } \\
\text { hak dirumah }\end{array}$ & $\begin{array}{l}\text { Perbedaan pelaksanaan } \\
\text { kewajiban dan hak dirumah }\end{array}$ & \\
\hline & & & $\begin{array}{l}\text { Menjelaskan pentingnya } \\
\text { melaksanakan kewajiban secara } \\
\text { seimbang dirumah }\end{array}$ & $\begin{array}{l}\text { Siswa mampu menjelaskan } \\
\text { pentingnya melaksanakan kewajiban } \\
\text { secara seimbang dirumah }\end{array}$ & $\begin{array}{l}\begin{array}{l}\text { Pentingnya melaksanakan } \\
\text { kewajiban dirumah }\end{array} \\
\end{array}$ & \\
\hline 3 & KD 3.3 & $\begin{array}{l}\text { Menjelaskan manfaat keberagaman } \\
\text { karakteristik individu dalam } \\
\text { kehidupan sehari - hari }\end{array}$ & $\begin{array}{l}\text { Menjelaskan manfaat keberagaman } \\
\text { karakteristik individu dalam } \\
\text { kehidupan sehari - hari }\end{array}$ & $\begin{array}{l}\text { Siswa mampu menjelaskan manfaat } \\
\text { keberagaman karakteristik individu } \\
\text { dalam kehidupan sehari - hari }\end{array}$ & $\begin{array}{l}\text { Manfaat keberagaman } \\
\text { karakteristik individu }\end{array}$ & $\mathrm{C}_{2}$ \\
\hline 4 & KD 3.4 & $\begin{array}{l}\text { Mengidentifikasi berbagai bentuk } \\
\text { keberagaman suku bangsa, sosial } \\
\text { dan budaya di Indonesia yang } \\
\text { terikat persatuan dan kesatuan }\end{array}$ & $\begin{array}{l}\text { Mengidentifikasi berbaga bentuk } \\
\text { keberagaman suku, sosial dan } \\
\text { budaya di Indonesia }\end{array}$ & $\begin{array}{l}\text { Siswa mampu mengidentifikasi } \\
\text { berbagai bentuk keberagaman suku, } \\
\text { sosial dan budaya di Indonesia }\end{array}$ & $\begin{array}{l}\text { Bentuk keberagaman suku } \\
\text { bangsa, sosial dan budaya di } \\
\text { Indonesia }\end{array}$ & c1 \\
\hline
\end{tabular}

\begin{tabular}{|c|c|l|l|l|l|l|}
\hline \multicolumn{5}{|c|}{ MATERI ESENSIAL } \\
PKN "4"
\end{tabular}


Based on the authors' observations, the curriculum development of MI Salafiyah Tajungsari during the Covid-19 pandemic is very different from the previous period. This difference can be seen from CHAPTER I INTRODUCTION to CHAPTER V CLOSING. The development of the regular emergency curriculum uses the national curriculum, while the Covid-19 pandemic uses the emergency curriculum.

The curriculum developed in MI Salafiyah Tajungsari uses an administrative model or uses the procedure of "line-staff" or command line "from top to bottom" (top-down) because the curriculum development initiative comes from the Director of Curriculum, Facilities, Institutions, and Students. Curriculum implementation is carried out in learning using online and offline models. There has been no evaluation of the curriculum conducted by the madrasah, so no curriculum improvements have been made. The form of curriculum development of an administrative model following the theory stated by Zainal Arifin that the curriculum was developed from education officials and then structurally implemented at the lower level (Arifin, 2011, p. 138)

The form of curriculum adaptation during the Covid-19 pandemic in MI Salafiyah Tajungsari Tlogowungu stated that the spirit and content of the curriculum provide learners' learning experience to follow and utilize the development of science following the definition of curriculum presented by Dadang Sukirman and Ali Nugraha that the curriculum not only emphasizes on the subject matter but the learning experience as an effort to have a positive impact on the personal development of learners (Sukirman \& Nugraha, 2018, p. 11).

The curriculum of MI Salafiyah Tajungsari also states that learning applies the principle that anyone is a teacher, anyone is a student, and anywhere is a class, following Syamsul Bahri's opinion that education is limited to learning in the classroom (Bahri, 2017). The emergency curriculum of MI Salafiyah Tajungsari also contains the design, implementation, evaluation, and adaptation conditions. This is in line with Sukiman's view that the curriculum is a series of processes that start from designing, implementing, evaluating, and improving the curriculum to form an ideal curriculum (Sukiman, 2015, p. 6).

When viewed in terms of function, the curriculum is developed structured from introduction to closing, programmatic during the Covid-19 pandemic, and considering the situation and conditions. Following Zainal Arifin's opinion, the curriculum is designed systematically, planned, and logically (Arifin, 2011, p. 13). The curriculum is used as a reference for teachers in carrying out learning during the Covid-19 pandemic, in line with the view of Abdullah Idi because the curriculum is used as a guide for teachers in the learning process (Idi, 2014, p. 165). The curriculum is used as a guide for students to learn online and 
offline in line with the opinion of Triyo Supriyatno and Umi Salamah that the curriculum is used as a guide for students in carrying out learning from home (Supriyatno \& Salamah, 2020).

Based on the principles of curriculum development, the curriculum of MI Salafiyah Tajungsari aims as a technical reference for learning during the Covid-19 pandemic can be said following the statement of Shaleh Musa Husein, who is oriented towards educational purposes during the Covid-19 pandemic, that education should continue to run even within limitations (Husein, 2009, p. 23). Implementation of curriculum documents according to the conditions experienced by the education unit following real-life experienced by students during the Covid-19 pandemic to achieve effective and efficient learning (Idi, 2014, p. 144). The curriculum adapted according to the conditions following the view of flexibility presented by Zaini (Zaini, 2009, p. 111). Learning applied by MI Salafiyah Tajungsari using online and offline systems (mixed), in li-Tze Lee and Jason C Hung research learning with diverse systems by combining offline and online is more effective than offline or online learning only (Lee, 2015).

Based on the data and analysis described above, it can be concluded that the form of curriculum adaptation developed by MI Salafiyah Tajungsari following the theoretical basis put forward by curriculum experts. The curriculum structure used by MI Salafiyah Tajungsari uses an emergency curriculum by simplifying the material into essential materials.

SDN Sitiluhur 02 Gembong made several adjustments to get around the Covid-19 pandemic by adapting the curriculum. Adaptation measures include simplifying essential competencies, taking necessary materials, reducing learning burdens, adding materials about Covid-19, and transforming face-to-face learning with distance learning. The form of curriculum simplification at SDN Sitiluhur 02 refers to simplifying Basic Competencies conducted by the Ministry of Education (Head of Research and Development Agency, 2020). The authors exemplify the 2013 curriculum comparison (Minister of Education and Culture, 2016) with the adaptation curriculum of SDN Sitiluhur 02 to clarify the reader's understanding further. The author took the example of grade 4 .

SDN Sitiluhur follows the simplification of Basic Competencies of the Ministry of Education, on the content of Citizenship Education, changing the KI-4 section; 4.1 The word "explain" is replaced with the word "writes", 4.2 the word "presents the results of identification" is replaced with the word "making a story", 4.3 the word "suggests" is replaced with the word "writes", and 4.4 the word "presents" is replaced with the word "writes". On the Bahasa Indonesia content, remove $\mathrm{KD} 3.2,4.2,3.4,4.4,3.5,4.5,3.8,4.8,3.10$, and 4.10. In the Natural Sciences (IPA) content, change the word "analyze the relationship" with the word "connect" in 
KD 3.1, change the word "present the report of observations" with the word "present the results of observations" in KD 4.1. Replaces the word "identify styles" with the word "linking style types" in $\mathrm{KD} 3.3$, replaces the word "demonstrating" with the word "presents test results" in KD 4.3, and eliminates KD 3.4 and 4.4. On the Social Sciences (IPS) content, remove KD 3.3 and 4.3. In the Math payload, remove KD 3.2, 4.2, 3.3, 4.3, 3.4, 4.4, 3.5, 4.5, 3.8, 4.8, 3.10, and 4.10. In the Islamic Religious Education (PAI) content, remove $\mathrm{KD} 3.5,4.5,3.8,4.8,3.12,4.12$, 3.21, and 4.21. On the content of Art culture and crafts (SBdP), still, maintain the existing KD. On the content of Physical Education, Sports, and Health, remove KD 3.3, 4.3, 3.8, and 4.8.

Table 1. KD Curriculum Adaptations changed from Curriculum 2013

\begin{tabular}{|c|c|}
\hline Lesson Content & Modified KD \\
\hline Citizenship Education & $\begin{array}{l}\text { change the KI- } 4 \text { section; } 4.1 \text { The word "explain" is replaced with the } \\
\text { word "writes", } 4.2 \text { the word "presents the results of identification" is } \\
\text { replaced with the word "making a story", } 4.3 \text { the word "suggests" is } \\
\text { replaced with the word "writes", and } 4.4 \text { the word "presents" is } \\
\text { replaced with the word "writes". }\end{array}$ \\
\hline Indonesian Language & Remove KD 3.2, 4.2, 3.4, 4.4, 3.5, 4.5, 3.8, 4.8, 3.10, and 4.10. \\
\hline Natural Sciences & $\begin{array}{l}\text { change the word "analyze the relationship" with the word "connect" } \\
\text { in } \mathrm{KD} 3.1 \text {, change the word "present the report of observation } \\
\text { results" with the word "present the results of observations" in } \mathrm{KD} \\
\text { 4.1. Replaces the term "identify styles" with the word "linking style } \\
\text { types" in } \mathrm{KD} 3.3 \text {, replaces the word "demonstrating" with the word } \\
\text { "presents test results" in KD 4.3, and eliminates KD } 3.4 \text { and } 4.4 \text {. }\end{array}$ \\
\hline Social Sciences & remove $\mathrm{KD} 3.3$ and 4.3 \\
\hline Math & Remove KD 3.2, 4.2, 3.3, 4.3, 3.4, 4.4, 3.5, 4.5, 3.8, 4.8, 3.10, and 4.10 \\
\hline $\begin{array}{l}\text { Islamic Religious } \\
\text { Education }\end{array}$ & Remove KD 3.5, 4.5, 3.8, 4.8, 3.12, 4.12, 3.21, and 4.21 \\
\hline $\begin{array}{l}\text { Cultural Arts and } \\
\text { Craftsmanship }\end{array}$ & Remain \\
\hline $\begin{array}{l}\text { Physical Education, } \\
\text { Sports, and Health }\end{array}$ & Remove KD 3.3, 4.3, 3.8, and 4.8 \\
\hline
\end{tabular}




\begin{tabular}{|c|c|c|c|}
\hline \multicolumn{2}{|r|}{ KOMPETENSI DASAR } & \multicolumn{2}{|r|}{ KOMPETENSI DASAR } \\
\hline 3.1 & $\begin{array}{l}\text { Memahami makna hubungan } \\
\text { simbol dengan sila-sila Pancasila }\end{array}$ & 4.1 & $\begin{array}{l}\text { Menjelaskan makna hubungan } \\
\text { simbol dengan sila-sila Pancasila } \\
\text { gebagai satu kesatuan dalam } \\
\text { kehidupan sehari-hari }\end{array}$ \\
\hline 3.2 & $\begin{array}{l}\text { Mengidentifikasi pelaksanaan } \\
\text { kewajiban dan bak sebagai warga } \\
\text { masyarakat dalam kehidupan } \\
\text { gehari-hari }\end{array}$ & 4.2 & $\begin{array}{l}\text { Menyajikan hasi identiflkasi } \\
\text { pelaksansan kewajiban dan bak } \\
\text { sebagai warga masyarakat dalam } \\
\text { kehidupan sehari-hari }\end{array}$ \\
\hline 3.3 & $\begin{array}{l}\text { Merjelaskan manfaat } \\
\text { keberagaman karakteristik } \\
\text { individu dalam kehidupan sehari- } \\
\text { hari }\end{array}$ & 4.3 & $\begin{array}{l}\text { Mengemukakan manfaat } \\
\text { lkeberagaman karakteristik } \\
\text { individu dalam kehidupan sehari- } \\
\text { hari }\end{array}$ \\
\hline 3.4 & $\begin{array}{l}\text { Mengidentifikasi berbagai bentuk } \\
\text { keberagaman sulcu bangsa, sosial, } \\
\text { dan budaya di tndonesia yang } \\
\text { terikat persatuan dan kesatuan }\end{array}$ & 4.4 & $\begin{array}{l}\text { Menyajikan berbagai bentuk } \\
\text { keberagaman suku bangsa, sosial, } \\
\text { dan budaya di Indonesia yang } \\
\text { terikat persatuan dan kesatuan }\end{array}$ \\
\hline
\end{tabular}

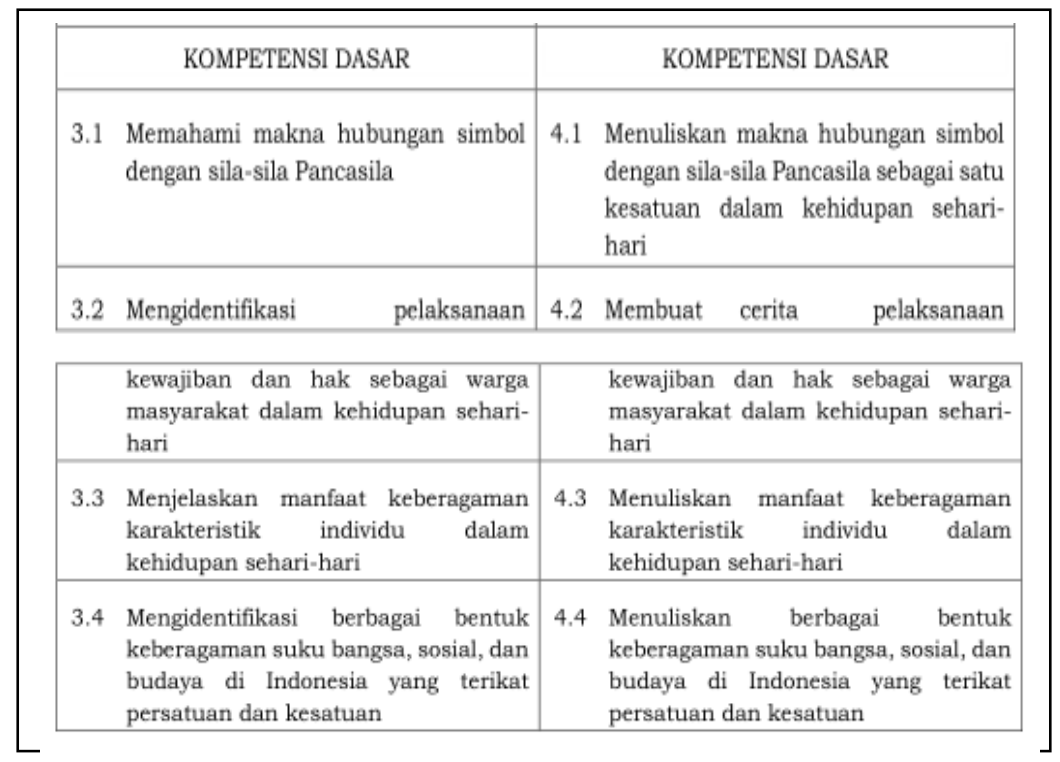

Figure 2. Comparison of Curriculum 2013 number 24 of 2016 Appendix 18 with Adaptation Curriculum of SDN Sitiluhur 02

Based on the author's analysis, the curriculum developed at SDN Sitiluhur 02 uses an administrative model or uses a "line-of-staff" or top-down command line procedure because the curriculum development initiative comes from the Ministry of Education. Curriculum implementation is carried out in learning using online and offline models. There has been no evaluation of the curriculum conducted by the school, so no curriculum improvement has been made. The form of curriculum development of the administrative model following the theory stated by Zainal Arifin that the curriculum was developed from education officials and then structurally implemented at the lower level (Arifin, 2011, p. 138) 
The curriculum form at SDN Sitiluhur 02 focuses on developing the learning experience by providing a vast opportunity for students to master the competencies needed for the present and future lives following the curriculum definition presented by Kamilati that the curriculum is materials prepared in learning to print competent learners (Kamilati, 2018). The curriculum is used as an operational guideline in carrying out education, following Hariyanto's opinion that the curriculum is a guideline used in carrying out the learning process at various levels of schooling planned in an organized manner (Hariyanto, 2019).

Curriculum determines the quality of learners through curriculum, resources, the content of the curriculum, learning process, position of learners, assessment of learning outcomes, and the relationship of learners with the community. This is in line with Mohammad Ansyar's opinion that the curriculum is a set of written plans on delivering lesson materials to students and oriented as a product that produces a learning experience (Ansyar, 2015, p. 57).

When viewed in terms of function, the curriculum is prepared from introduction to closing, careful planning, and reasoning. Following Zainal Arifin's opinion, the curriculum is designed systematically, planned, and logically (Arifin, 2011, p. 13). However, the curriculum designed is not in line with Abdul Wafi's opinion that the curriculum should be created under the desired conditions (Wafi, 2017). Since most discussions in the curriculum still focus on curriculum development in general, there is little discussion about the curriculum during the Covid-19 pandemic.

Based on the principle of curriculum development, it can be said that the curriculum of SDN Sitiluhur 02 is oriented towards national educational objectives and primary education objectives, by Shaleh Musa Husein's statement that is oriented towards educational purposes (Husein, 2009, p. 23). Learning mentioned in the curriculum is required to give complete meaning to students. This is under Hidayat's view that the curriculum contains integrity that can develop people as a whole (Hidayat, 2013, p. 78). The curriculum is prepared continuously based on the level of learners following the view of Abdullah Idi with sustainable principles because each level of education can be continued (Idi, 2014, p. 145).

Based on the data and analysis presented above, it can be concluded that the form of curriculum developed by SDN Sitiluhur 02 is following the theoretical basis put forward by curriculum experts but still needs to be developed and detailed in more depth during the Covid-19 pandemic. Meanwhile, the form of curriculum used by SDN Sitiluhur 02 is to simplify essential competencies in the curriculum. 


\section{Teacher Strategies for Developing and Implementing Adaptable Curriculum}

Strategy is a plan on how to utilise the potential and means that already exist to improve the efficiency and effectiveness of an activity. Strategies can be expressed to achieve systematically and logically formulated goals (Hanum, 2016, p. 2). Strategy is a pattern that is planned and set in conducting activities intentionally. The strategy includes the purpose of the training, anyone involved, the content of the action, the process of activities, and supporting facilities (Majid, 2013, p. 4).

Not all learning strategies are suitable to achieve all the learning objectives that have been formulated. Each system has its peculiarities. Teachers should be able to choose methods that are considered ideal in implementing the curriculum. The general principle in using learning strategies is competency-oriented to stimulate student activity and develop student behavior in a better direction in terms of cognitive, affective, and psychomotor (Hamruni, 2012).

The curriculum should be prepared by paying attention to the condition of learners both in terms of sociology and psychology. The sociological aspect relates to the geographical and cultural location of the learner, while the psychological aspect relates to the psychic condition of the learner (Zamili, 2020). In terms of learning, the strategy aims to facilitate teachers in overcoming obstacles experienced by students so that the learning process can take place effectively and efficiently (Malik \& Nugraheni, 2020).

Components to streamline learning one of them with the utilization of technological advances. Teachers should be able to utilize technology in today's learning process. The implementation of e-learning, Google Classroom, Moodle, WhatsApp Groups, Telegram Groups, Zoom, and Google Meet is an example of a medium that allows teachers to interact directly with students (online). It will enable students to learn independently (Malik, 2020b). Teaching teachers to determine student success requires great teachers to know the right and surefire way to teach certain learning materials (Zaenuddin, 2017, p. 212). Although learning is carried out from home, students should strive to keep learning and continue to be given motivation to like activities by prioritizing reading a lot because reading is the key to unlocking science (Malik \& Maemunah, 2020).

Teachers at MI Salafiyah Tajungsari have implemented various strategies to streamline learning, as well as implement online learning with the following steps:

a. The homeroom teacher provides the WhatsApp class group as a learning communication resource to deliver the learning materials and assignments to the learners 
b. The teacher directs the parents to guide their children's learning through the WhatsApp

c. Teachers group explaining the materials and tasks that will be performed by each student and includes examples of the expected final results to strengthen the explanation of the lesson materials. Materials can be visual, audio, or audiovisual

d. Q\&A sessions are always available in the time of assignment work if there is something that learners do not understand

e. Learning results in the form of writings, images, and videos collected through the WhatsApp Group or directly contained in the home of their respective teachers.

f. Teachers provide feedback directly after students collect assignments.

While the implementation of offline learning must adhere to the following signs:

a. The teacher asks the learner to record things that are not yet understood so that on the next visit, the teacher can explain (because the learning time is too short)

b. Teachers conduct learning meetings consisting of 5-10 children per group 2 times a week

c. Teachers provide direct direction and explanation while strengthening discussions that students don't know about online learning

d. Teachers always direct children to maintain health protocols.

The role of research in MI Salafiyah Tajungsari with literature studies published by the author, namely to provide the innovation of learning strategies conducted by educators in the era of the Covid-19 pandemic, is full of limitations while giving students the right to obtain education by online and offline. Online using WhatsApp Groups while offline using face-toface is limited. The era of the Covid-19 pandemic does make students and educators depressed because they have to get out of face-to-face learning habits, but this is a tremendous leap in the world of education so that the mastery of science and technology is getting massive for both educators and students. SDN Sitiluhur 02 has implemented strategies to streamline learning, namely: organizing socialization on distance learning, organizing workshops on Microsoft Teams, registering Jateng Pintar accounts, effectively working groups of teachers in the Wiyata Kencana Group with materials to support distance learning, and carrying out monitoring, monitoring, and supervision of distance learning implemented by teachers.

SDN Sitiluhur 02 Gembong in carrying out the learning process using online and offline models. The online model is done through educational television broadcasts and other models that have been mutually agreed upon between teachers and guardians of students with 
teacher guidance through the Student Guardian Whatsapp Group. In contrast, offline is done by doing tasks uploaded through Whatsapp Group Guardians of Learners. The students' work results are uploaded to the mobile number of the class teacher and the teacher of the assignment subject to be corrected (KTSP SD Sitiluhur 02, 2021).

The role of research at SDN Sitiluhur 02 with the literature study that has been described by the author, which is to provide the innovation of learning strategies conducted by educators in the era of the Covid-19 pandemic that is full of limitations while giving students the right to obtain education by online and offline. How to use WhatsApp Groups online while offline using television media and textbooks. Educators must be more creative and innovative in implementing learning to remain motivated in learning anywhere in any condition.

\section{Impact of Curriculum Development and Implementation on Competency Target Achievement by Using Adaptation Curriculum}

Priority materials presented in the adaptation curriculum are essential materials, while students can learn other materials independently. The source of necessary materials can be developed from student books, teacher's books, social phenomena, or modules that have been provided by the government (Munajim, Barnawi, \& Fikriyah, 2020). Some of the steps taken in this strategy include choosing materials that are fundamental to the learners. Second, relevance, i.e., the material must be associated with a perspective of values, aspirations, principles, and community problems that will help learners become good citizens. Third, Utilities, the curriculum should contain things that are useful in the present and future. The new standard era after the upcoming Covid-19 can be a learning moment for significant, relevant, and helpful content (Cahapay, 2020).

The Covid-19 pandemic has changed almost the entire system order that has been developed by the government, including the education system. The most affected education system is the curriculum because it contains everything related to the teaching and learning process. The burgeoning curriculum cannot be maintained. The Covid-19 pandemic has had a significant impact on the learning process in an emergency. Besides, the demands of industrial revolution 4.0 are also enormous. Human thinking skills are needed to not lose their existence as civilized beings who can face the challenges, problems, burdens of life, and economy in this century (Malik, 2020a). 
Curriculum changes usually take years to be researched, enforced and evaluated. However, the current crisis has forced academics to make adjustments in a short time. Adverse effects such as time pressures, changes in judgment, and implications in student engagement and relationships are somewhat offset by positive consequences, such as the potential to create new resources and encourage academic collaboration (Longhurst, 2020).

The impact of the development and implementation of the curriculum is positive and negative. The positive impact when learning is done online children can explore their knowledge not only from books but through any medium be it, the internet, YouTube, or even other educational media. The negative impact, sometimes children do not make good use of time and smartphones. They even enjoy playing games rather than learning. Achievement of competency targets can not be maximized because there are still a tiny number of guardians of students who are busy working so can not guide their children in distance learning. There is still a small percentage of children who do not have gadgets because usually one house one device (smartphone), most students still use parents' widgets, sometimes internet signals are challenging to use, children still need material explanation directly from the teacher.

Obstacles in the development and implementation of curriculum adaptation during covid-19, among which teachers tend to have difficulty managing distance learning, not all parents have time and can accompany their children, the majority of parents of madrasah students are farmers or labourers, so there are still many parents who have difficulty and do not understand in using smartphones well and are less able to access the internet, parents have a problem in understanding lessons, lack of availability of internet quota due to financial limitations, the majority of students have difficulty concentrating in learning from home students feel saturated due to continuous isolation and not together with playmates, there are still some students who do not have their smartphones, some students are among the underprivileged families, so still mind if they have to buy a large amount of quota in each month, and limited funds to access the internet network.

The result of the adaptation curriculum is the simplification of Basic Competencies for schools under the auspices of the Ministry of Education and Culture and the use of essential materials for madrasah under the aegis of the Ministry of Religion. The application of a wellprepared curriculum has not had a significant impact because of the limitations that various elements have in it. This data is based on interviews, observations, and documentation from MI Salafiyah Tajungsari and SDN Sitilihur 02 with triangulation techniques of sources and methods. 


\section{Conclusion}

The form of curriculum adaptation in MI Salafiyah Tajungsari uses an emergency curriculum by simplifying the subject matter into essential materials. In contrast, SDN Sitiluhur 02 uses the national curriculum by simplifying critical competencies. The strategies teachers use to develop and implement adaptable curricula are both online and offline, which models the development and implementation of curriculum adaptation in terms of the learning process. Many students do not understand the explanation of materials provided by teachers when using the online model, and competency targets have not been achieved to the maximum. The application of a well-prepared curriculum has not had a significant impact because of the limitations that various elements have in it. The author recommends that teachers be more creative and innovative in adapting the best learning techniques in their respective regions to all their limitations.

\section{REFERENCES}

Ansyar, M. (2015). Kurikulum (Hakikat, Fondasi, Desain, dan Pengembangan). Jakarta: Kencana Prenadamedia Group.

Arifin, Z. (2011). Konsep dan Model Pengembangan Kurikulum. Bandung: Remaja Rosda Karya.

Arifin, Z. (2018). Manajemen Pengembangan Kurikulum Pendidikan Islam: Teori Dan Praktik. Yogyakarta: UIN Sunan Kalijaga.

Asnawan, A. (2018). Urgensi Pengembangan Kurikulum Pesantren dalam Meningkatkan Mutu Pendidikan. FALASIFA: Jurnal Studi Keislaman, (Query date: 2021-01-15 09:49:42). $\quad$ Retrieved from http://ejournal.inaifas.ac.id/index.php/falasifa/article/view/128

Atiqoh, L., \& Saputro, B. (2017). Kurikulum Pendidikan Agama Islam Berbasis Lingkungan sebagai Penguatan Pendidikan Humanistik di Sekolah Adiwiyata. Edukasia: Jurnal Penelitian Pendidikan Islam, 12(2), 285-308. https://doi.org/10.21043/edukasia.v12i2.2492

Audia, E. D. (2019). Implementasi Kurikulum Pendidikan Islam di Indonesia dan Malaysia. UIN Sunan Kalijaga Yogyakarta, Yogyakarta.

Bahri, S. (2017). Pengembangan Kurikulum Dasar dan Tujuannya. Jurnal Ilmiah Islam Futura, 11(1), 15-34.

Bahrissalim, B., \& Fauzan, F. (2018). Evaluasi Kurikulum Pelatihan dalam Meningkatkan 
Kompetensi Pedagogik Guru PAI di Balai Diklat Keagamaan Jakarta. Edukasia : Jurnal Penelitian Pendidikan Islam, 13(1), 25-52. https://doi.org/10.21043/edukasia.v13i1.2779

Bchetnia, M., Girard, C., Duchaine, C., \& Laprise, C. (2020). The outbreak of the novel severe acute respiratory syndrome coronavirus 2 (SARS-CoV-2): A review of the current global status. Journal of Infection and Public Health.

Cahapay, M. B. (2020). Rethinking education in the new normal post-COVID-19 era: A curriculum studies perspective. Aquademia, 4(2), ep20018.

Cahyani, S. A., \& Satriyani, F. Y. (2020). Penerapan Kurikulum 2013 di SDSN Kalibata 11 Pagi. PEDAGOGIK: Jurnal Pendidikan, 7(2), 348-376.

Darmalaksana, W. (2020). Metode Penelitian Kualitatif Studi Pustaka dan Studi Lapangan. Pre-Print Digital Library UIN Sunan Gunung Djati Bandung.

Director of Curriculum, Facilities, Institutions, and Students. (2020, July 6). Essential Material for Madrasah Ibtidaiyah. Minister of Religious Affairs.

Director-General of Islamic Education. (2020, Mei). Keputusan Direktur Jenderal Pendidikan Islam Nomor 2791 Tahun 2020 Tentang Panduan Kurikulum Darurat Pada Madrasah. The Ministry of Religious Affairs.

Fauziyati, D. (2019). Pengembangan Kurikulum Program Magister Pendidikan Agama Islam Mengacu KKNI dan SN-DIKTI di PTKI. UIN Sunan Kalijaga Yogyakarta, Yogyakarta.

Giannis, D., Ziogas, I. A., \& Gianni, P. (2020). Coagulation disorders in coronavirus infected patients: COVID-19, SARS-CoV-1, MERS-CoV and lessons from the past. Journal of Clinical Virology, 104362.

Habiby, W. N. (2017). Manajemen Adaptasi Pembelajaran Kurikulum 2013 ke Kurikulum 2006 (KTSP) pada Siswa Kelas I SDN Sondakan Surakarta. Profesi Pendidikan Dasar, $1(2), 180-189$.

Hamalik, O. (2013). Dasar-Dasar Pengembangan Kurikulum. Bandung: Remaja Rosda Karya.

Hamruni. (2012). Strategi Pembelajaran. Yogyakarta: Insan Madani.

Hanum, R. J. \& L. (2016). Strategi Belajar Mengajar. Yogyakarta: Deepublish.

Hariyanto, M. (2019). Pengembangan Kurikulum Berbasis Adiwiyata di Sekolah Menengah Kejuruan. EL-HIKMAH: Jurnal Kajian Dan Penelitian Pendidikan Islam. Retrieved from https://journal.uinmataram.ac.id/index.php/elhikmah/article/view/867

Head of Research and Development Agency. (2020, Agustus). SK Kabalitbang Nomor 018/H/KR/2020 tentang Kompetensi Inti dan Kompetensi Dasar Pelajaran pada Kurikulum 2013 pada Pendidikan Anak Usia Dini, Pendidikan Dasar, dan Pendidikan Menengah Berbentuk Sekolah Menengah Atas untuk Kondisi Khusus. Secretariat of the 
Head of the Research and Development Agency.

Hidayat, S. (2013). Pengembangan Kurikulum Baru. Bandung: Remaja Rosda Karya.

Hidayati, N. (2016). Konsep Integrasi Tripusat Pendidikan Terhadap Kemajuan Masyarakat. Edukasia: Jurnal Penelitian Pendidikan Islam, 11(1).

Husein, S. M. (2009). Syarah Faraid Bahiyah Nadzam Kaidah Fikih. Beirut-Lebanon: Resalah Publisher.

Idi, A. (2014). Pengambangan Kurikulum: Teori dan Praktik. Jakarta: Raja Grafindo Persada.

Julaeha, S. (2019). Problematika Kurikulum Dan Pembelajaran Pendidikan Karakter. Jurnal Penelitian Pendidikan Islam, [SL], 7(2), 157-182.

Kamilati, N. (2018). Analisis Komponen Penilaian pada Rencana Pelaksanaan Pembelajaran sebagai Acuan Pengembangan Kurikulum Diklat Teknis Substantif Guru. Edukasi.

Krissandi, A. D. S., \& Rusmawan, R. (2015). Kendala Guru Sekolah Dasar dalam Implementasi Kurikulum 2013. Jurnal Cakrawala Pendidikan, 34(3). https://doi.org/10.21831/cp.v3i3.7409

KTSP SD Sitiluhur 02. (2021, February 10). Kurikulum Tingkat Satuan Pendidikan SD Sitiluhur 02.

Lai, C.-C., Shih, T.-P., Ko, W.-C., Tang, H.-J., \& Hsueh, P.-R. (2020). Severe acute respiratory syndrome coronavirus 2 (SARS-CoV-2) and corona virus disease-2019 (COVID-19): The epidemic and the challenges. International Journal of Antimicrobial Agents, 105924.

Lee, L. T. (2015). Effects of blended e-Learning: A case study in higher education tax learning setting. Human-Centric Computing and Information Sciences, 5(1). https://doi.org/10.1186/s13673-015-0024-3

Longhurst, G. J. (2020). Strength, Weakness, Opportunity, Threat (SWOT) Analysis of the Adaptations to Anatomical Education in the United Kingdom and Republic of Ireland in Response to the Covid-19 Pandemic. Anatomical Sciences Education, 13(3), 301-311. https://doi.org/10.1002/ase.1967

Majid, A. (2013). Strategi Pembelajaran. Bandung: Remaja Rosda Karya.

Malik, M. S. (2020a). Analisis Materi Pokok SBDP MI/SD Kurikulum 2013 Abad 21. ELEMENTARY: Islamic Teacher Journal, 8(1), 59-82.

Malik, M. S. (2020b). Technological Innovation in Integration and Interconnection of Science in Islamic Higher Education. Sunan Kalijaga International Journal on Islamic Educational Research, 4(2), 1-20.

Malik, M. S., \& Maemunah, M. (2020). Kemampuan Literasi Baca Tulis Anak Usia Dasar (Studi Analisis Perkembangan Bahasa Anak Usia 7-12 Tahun di Madrasah Ibtidaiyah (MI) Salafiyah Tajungsari Kecamatan Tlogowungu Kabupaten Pati). JIP (Jurnal Ilmiah 
PGMI), 6(2), 195-214.

Malik, M. S., \& Nugraheni, A. S. (2020). Strategi Interactive Digital Learning untuk Meningkatkan Pemahaman Bacaan pada Anak Slow Learner. EduHumaniora/ Jurnal Pendidikan Dasar Kampus Cibiru, 12(2), 176-182.

Maslahah, A. U. (2018). Penerapan Kurikulum Mengacu KKNI dan Implikasinya Terhadap Kualitas Pendidikan di PTKIN. Edukasia: Jurnal Penelitian Pendidikan Islam, 13(1), 227-248. https://doi.org/10.21043/edukasia.v13i1.5717

Miles, M. B., \& Huberman, A. M. (2009). Analisis Data Kualitatif: Buku Sumber tentang Metode-Metode Baru. Jakarta: UI Press.

Minister of Education and Culture. (2016, June 7). Permendikbud Tahun 2016 Nomor 24 tentang Kompetensi Inti dan Kompetensi Dasar Pelajaran pada Kurikulum 2013 pada Pendidikan Dasar dan Pendidikan Menengah. The Ministry of Education and Culture.

Ministry of Education and Culture Website Manager. (2020, August 7). Kemendikbud Terbitkan Kurikulum Darurat pada Satuan Pendidikan dalam Kondisi Khusus. Retrieved February 28, 2021, from The Ministry of Education and Culture website: https://www.kemdikbud.go.id/main/blog/2020/08/kemendikbud-terbitkankurikulum-darurat-pada-satuan-pendidikan-dalam-kondisi-khusus

Munajim, A., Barnawi, B., \& Fikriyah, F. (2020). Pengembangan Kurikulum Pembelajaran di Masa Darurat. DWIJA CENDEKIA: Jurnal Riset Pedagogik, 4(2), 285-291.

Prastowo, A., \& Fitriyaningsih, F. (2020). Learning Material Changes as the Impact of the 2013 Curriculum Policy for the Primary School/Madrasah Ibtidaiyah. Edukasia : Jurnal Penelitian Pendidikan Islam, 15(2), 251-276. https://doi.org/10.21043/edukasia.v15i2.7947

Rigianti, H. A. (2020). Kendala Pembelajaran Daring Guru Sekolah Dasar Di Banjarnegara. Elementary School: Jurnal Pendidikan Dan Pembelajaran Ke-SD-An, 7(2).

Soeratman, S. (2016). Adaptasi Kurikulum Pendidikan Inklusif Siswa dengan Hambatan Sosial Emosional di Sekolah Dasar. Perspektif Ilmu Pendidikan, 30(1), 33-40.

Sukiman. (2015). Pengembangan Kurikulum Perguruan Tinggi. Bandung: Remaja Rosda Karya.

Sukino. (2017). Pengembangan Kurikulum Madrasah di Daerah Transisi. Tarbawi: Jurnal Keilmuan Manajemen Pendidikan, 3(01), 24-42.

Sukirman, D., \& Nugraha, A. (2018). Hakikat Kurikulum. Jakarta: Diklat PM4PGTK.

Suparlan. (2012). Tanya Jawab Pengembangan Kurikulum dan Materi Pembelajaran. Jakarta: Bumi Aksara.

Supriatna, R. D., \& Ratnaningsih, S. (2017). Indonesian Madrasah in the Era of Globalization. 
TARBIYA: Journal of Education in Muslim Society, 4(1), 89-103. https://doi.org/10.15408/tjems.v4i1.5908

Supriyatno, T., \& Salamah, U. (2020). Implementation of Curriculum Innovation and Islamic Education Learning Basic Education/Implementasi Inovasi Kurikulum dan Pembelajaran Pendidikan Agama Islam Pendidikan Dasar. Al-Mudarris: Journal Of Education, 3(1), 114-14. (SDIT Ahmad Yani Malang). https://doi.org/10.32478/al-mudarris.v3i1.365

Wafi, A. (2017). Konsep dasar Kurikulum Pendidikan Agama Islam. EDURELIGIA: Jurnal Pendidikan Agama Islam, 1(2), 133-139.

Winarno, A. (2015). Adaptation Entrepreneurship Education Model Curriculum 2013 for SMK (Description Preparation and Implementation Barriers in School)/Model Pendidikan Kewirausahaan Adaptasi Kurikulum 2013 bagi SMK (Diskripsi Persiapan dan Hambatan Penerapan di Sekolah). JPBM (Jurnal Pendidikan Bisnis Dan Manajemen), 1(1), 1-10.

Zaenuddin. (2017). The Best Techers, 200 Dalil Motivasi untuk Menjadi Guru Terbaik dan Sukses. Jakarta: Indeks.

Zaini, M. (2009). Pengembangan Kurikulum: Konsep Implementasi Evaluasi dan Inovasi. Yogyakarta: Teras.

Zamili, U. (2020). Peranan Guru dalam Pengembangan Kurikulum. JURNAL PIONIR, 6(2). 